University of Rhode Island

DigitalCommons@URI

The Rhode Island Current Conditions Index

Economics

$10-2015$

\title{
Rhode Island Current Conditions Index - October 2015
}

Leonard Lardaro

University of Rhode Island, lardaro@uri.edu

Follow this and additional works at: https://digitalcommons.uri.edu/ricci

Part of the Econometrics Commons

Terms of Use

All rights reserved under copyright.

\section{Recommended Citation}

Lardaro, Leonard, "Rhode Island Current Conditions Index -- October 2015" (2015). The Rhode Island Current Conditions Index. Paper 142.

https://digitalcommons.uri.edu/ricci/142

This Article is brought to you for free and open access by the Economics at DigitalCommons@URI. It has been accepted for inclusion in The Rhode Island Current Conditions Index by an authorized administrator of DigitalCommons@URI.For more information, please contact digitalcommons-group@uri.edu. 


\title{
CURRENT CONDITIONS
}

LEONARD LARDARO, URI

\author{
Available Online: http:/ / www .Ilardaro.com/ current.htm \\ Blog: http:/ / rieconomy.blogspot.com \\ Twitter: @ladardo
}

VOL XXLT

NUMBER 11

OCT 2015
What a way to begin the fourth quarter! The Current Conditions Index for October fell all the way to 67, its lowest value since May. This should not come as a complete surprise, however, since the US economy has been slowing, especially manufacturing, which was impacted here as well this month. And, as I have recently noted, monthly (versus yearly) activity levels for a number of $\mathrm{CCl}$ indicators have recently begun to deteriorate.

To some extent this reflects an asymmetry Rhode Island has been stuck with for a very long time- when the national economy picks up, we catch up, but only eventually. But when the national economy slows, Rhode Island is impacted almost immediately. Until we make our state's economy more competitive and transition to a greater and more meaningful presence in growthoriented areas, this asymmetry will unfortunately persist.

While eight of the twelve $\mathrm{CCl}$ indicators improved in October, our overall weakness was concentrated in the goods-producing sector. Both manufacturing and construction activity here did not do well in October. Potentially troubling, and something I have yet to be able to understand, is that new home construction, while beyond its cyclical bottom, has not yet entered a well-defined uptrend since the end of last winter's unseasonably cold weather. New home construction, in terms of Single-Unit Permits, fell by 15.3 percent compared to last October, rising only three times since April. Less of a surprise, as noted above, is manufacturing

\begin{tabular}{|l|r|r|}
\hline \multicolumn{3}{|c|}{ CCI Indicators - \% Change } \\
\hline Government Employment & -0.8 & \\
\hline US Consumer Sentiment & 3.5 & $\mathrm{Y}$ \\
\hline Single-Unit Permits & -15.3 & \\
\hline Retail Sales & 1.0 & $\mathrm{Y}$ \\
\hline Employment Services Jobs & 1.2 & $\mathrm{Y}$ \\
\hline Priv. Serv-Prod Employment & 1.7 & $\mathrm{Y}$ \\
\hline Total Manufacturing Hours & -1.2 & \\
\hline Manufacturing Wage & -2.8 & \\
\hline Labor Force & 1.1 & $\mathrm{Y}$ \\
\hline Benefit Exhaustions & -23.9 & $\mathrm{Y}$ \\
\hline New Claims & -16.4 & $\mathrm{Y}$ \\
\hline Unemployment Rate (change) & -1.8 & $\mathrm{Y}$ \\
\hline \multicolumn{2}{|c|}{$\mathrm{Y}=$ Improved Value } \\
\hline
\end{tabular}

weakness, reflective of the national trend. Total Manufacturing Hours, a measure of manufacturing sector strength, fell by 1.2 percent in October, its fifth decline in the last seven months.

As disappointing as the $\mathrm{CCl}$ 's October value is, at least it matched the value from one year ago. As such, October marked the eighth month for which the $\mathrm{CCl}$ has either matched or exceeded its yearearlier value. While the pace of Rhode Island's current recovery accelerated in the second quarter, as seen in both our 4 percent rate of GDP growth and a breakout in CCl values, the added momentum gained in the third quarter appears to be dissipating.
As always, it is critical that we keep all of what is occurring in perspective. While we slowed a bit in October, at least we had something to slow from. It's been a while since we've been able to say that! And, while the officially published labor market data indicate that payroll employment has been declining since July, my simulations indicate those declines are likely to be revised away in February. My concern moving forward is that both our employment and labor force participation rates have been declining since J uly. Worse yet, both rates remain well below recession levels. Once again, our Unemployment Rate is falling for the wrong reasons.

Eight of the $\mathrm{CCl}$ indicators improved in October, including three of the $\mathrm{CCl}$ 's leading indicators. Ironically, those three were able to beat difficult comps from a year ago, while the two non-improving leading indicators failed to beat fairly easy comps.

US Consumer Sentiment increased once again, albeit at a slower rate than has been true recently $(+3.5 \%)$. This was its thirteenth consecutive improvement. Employment Service Jobs, which includes temporary employment and is a prerequisite to employment growth, rose by 1.2 percent, well below its recent high rate. Finally, New Claims, a leading labor market indicator that reflects layoffs, fell by 16.4 percent in October.

Retail Sales growth slowed to one percent in October, its seventeenth consecutive improvement. Private Service-Producing Employment rose by 1.7 percent, yet another indicator with slowing recent growth. Government Employment fell again in October $(-0.8 \%)$. Benefit Exhaustions, which reflects longer-term unemployment, declined by 23.9 percent relative to last year. Our Manufacturing Wage fell (if you believe this) for the twentieth consecutive time $(-2.8 \%)$, and our Labor Force sustained its recent uptrend on a yearly but not monthly basis $(+1.1 \%)$.



In an inauspicious beginning to the fourth quarter, the Current Conditions Index fell sharply from 83 in September to 67 in October, moving us back to a level we haven't seen since May. The slowdown in national growth, which had been adversely affecting Rhode Island's month-to-month performance, appears to have begun hurting our year-over-year momentum. Fortunately, we should begin to see the economic benefits from the legislation passed in the last session start early next year, which should help us through what might prove to be a rough patch. And, yes, it could be far worse - let's thank God that Rhode Island isn't an oil producing state.

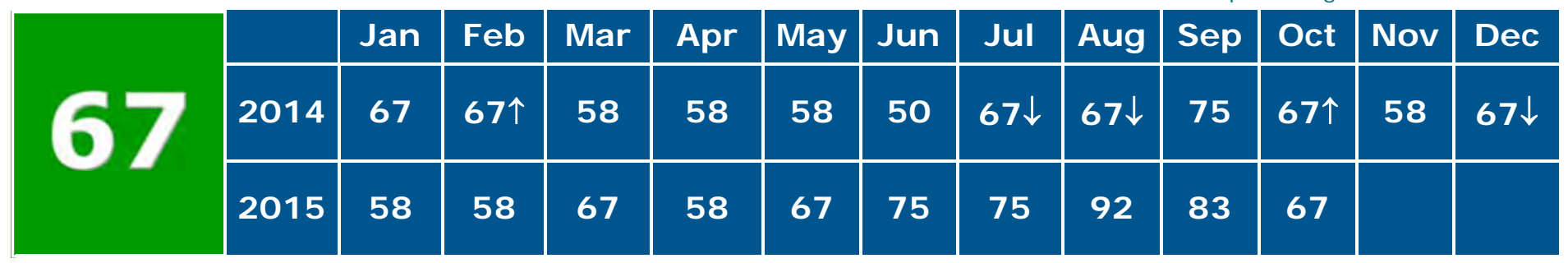

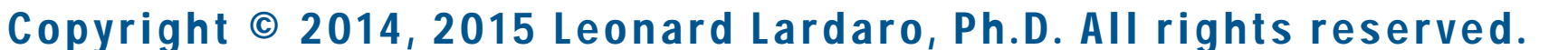

